\title{
The Influence of Cycle Sputtering Deposition on the Properties of $\mathrm{Cu}_{2} \mathrm{ZnSnS}_{4}$ Thin Films
}

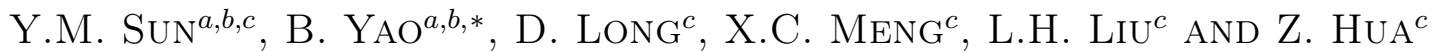 \\ ${ }^{a}$ State Key Lab of Superhard Material and College of Physics, Jilin University, Changchun 130023, P.R. China \\ ${ }^{b}$ Key Laboratory of Physics and Technology for Advanced Batteries of Ministry of Education, College of Physics, \\ Jilin University, Changchun, 130012, China \\ ${ }^{c}$ Key Laboratory of Functional Materials Physics and Chemistry of the Ministry of Education, \\ Jilin Normal University, Siping 136000, P.R. China \\ (Received March 27, 2015; in final form May 6, 2016) \\ Three kinds of precursor thin films with stacking orders of $\mathrm{Cu} / \mathrm{Sn} / \mathrm{ZnS}, \mathrm{Cu} / \mathrm{Sn} / \mathrm{ZnS} / \mathrm{Cu} / \mathrm{Sn} / \mathrm{ZnS}$ and \\ $\mathrm{Cu} / \mathrm{Sn} / \mathrm{ZnS} / \mathrm{Cu} / \mathrm{Sn} / \mathrm{ZnS} / \mathrm{Cu} / \mathrm{Sn} / \mathrm{ZnS}$ were prepared by magnetron sputtering and annealed with sulfur powder. \\ The microstructure, morphology and optical properties of thin films were investigated by X-ray diffraction, the \\ Raman scattering, scanning electron microscopy and UV-visible spectrophotometer. The increase of cycle number \\ decreases the sulfurizing temperature of the formation of $\mathrm{Cu}_{2} \mathrm{ZnSnS}_{4}$ phase. Chemical composition can be con- \\ trolled by cycle sputtering deposition. After sulfurizing at $500{ }^{\circ} \mathrm{C}$, the particle size and the band gap increase with \\ increasing cycle number.
}

DOI: 10.12693/APhysPolA.129.1169

PACS/topics: 78.40.Fy

\section{Introduction}

$\mathrm{Cu}_{2} \mathrm{ZnSnS}_{4}$ (CZTS) is one of the most interesting materials for an absorption layer of thin-film solar cells. In recent years, lots of investigations have been involved in CZTS owing to their excellent properties. The constituent elements of CZTS are abundance and nontoxic. The absorption coefficient is over $10^{4} \mathrm{~cm}^{-1}$ and the suitable optical band-gap is about $1.5 \mathrm{eV}$. The morphology, composition and property of the thin films are largely dependent on the deposition sequence of metal layers. The fabrications and properties of CZTS thin film with special sequence have been studied extensively. Araki et al. studied the effect of six kinds of precursors with different stacking sequences on the properties of CZTS thin films by the sequential electron beam evaporation method [1]. Seung Wook Shin et al. fabricated three kinds of CZTS thin films with three stacking orders of $\mathrm{ZnS} / \mathrm{Cu} / \mathrm{SnS}_{2} /$ glass, $\mathrm{Cu} / \mathrm{SnS}_{2} / \mathrm{ZnS} /$ glass and $\mathrm{SnS}_{2} / \mathrm{ZnS} / \mathrm{Cu}$ glass by the sequential sputtering method [2]. Zhang et al. fabricated the CZTS thin films with $\mathrm{S} / \mathrm{Sn} / \mathrm{S} / \mathrm{Cu} / \mathrm{S} / \mathrm{Zn} / \mathrm{S} / \mathrm{Cu}$-layers by electrodepositing [3]. Hyesun Yoo et al. fabricated several $\mathrm{Cu}^{-}$ Zn-Sn stacked films and converted them to CZTS films by sulfurization process [4]. In our previous study [5], six kinds of thin film were prepared with different stacking sequences using $\mathrm{Cu}$, Sn and $\mathrm{ZnS}$ targets by magnetron sputtering and the stacking sequence $\mathrm{Cu} / \mathrm{Sn} / \mathrm{ZnS}$ after sulfurizing has the best properties. Therefore, we choose the stacking sequence $\mathrm{Cu} / \mathrm{Sn} / \mathrm{ZnS}$ as the

\footnotetext{
*corresponding author; e-mail: binyao@jlu.edu.cn
}

basic research object. The $\mathrm{Cu} / \mathrm{Sn} / \mathrm{ZnS} / \mathrm{Cu} / \mathrm{Sn} / \mathrm{ZnS}$ and $\mathrm{Cu} / \mathrm{Sn} / \mathrm{ZnS} / \mathrm{Cu} / \mathrm{Sn} / \mathrm{ZnS} / \mathrm{Cu} / \mathrm{Sn} / \mathrm{ZnS}$ precursor thin films were also prepared by magnetron sputtering and sulfurized into CZTS in this paper. The influence of cycle number on the properties of three kinds of thin films was studied.

\section{Experimental}

Three kinds of stacked metallic films were deposited on soda lime glass substrates by sputtering. The sputtering conditions are shown in Table I. Three kinds of precursor thin films were annealed with sulfur powder for $2 \mathrm{~h}$, respectively, in a tubular furnace with two zones [6], where one zone was for laying the precursor thin film and the other was for laying S source. Both the sample temperature and $\mathrm{S}$ source temperature are $500^{\circ} \mathrm{C}$.

TABLE I

The sputtering conditions of three kinds of precursor thin films. In multiple structures same layers have equal thicknesses.

\begin{tabular}{c|c|c}
\hline \hline Sample No. & Target & Thickness of each layer $[\mathrm{nm}]$ \\
\hline Sample 1 & $\mathrm{Cu}$ & 120 \\
$\mathrm{Cu} / \mathrm{Sn} / \mathrm{ZnS}$ & $\mathrm{Sn}$ & 110 \\
$/$ glass & $\mathrm{ZnS}$ & 210 \\
\hline $\mathrm{Sample} 2$ & $\mathrm{Cu}$ & 60 \\
$2 \times(\mathrm{Cu} / \mathrm{Sn} / \mathrm{ZnS})$ & $\mathrm{Sn}$ & 55 \\
$/$ glass & $\mathrm{ZnS}$ & 105 \\
\hline $\mathrm{Sample} 3$ & $\mathrm{Cu}$ & 40 \\
$3 \times(\mathrm{Cu} / \mathrm{Sn} / \mathrm{ZnS})$ & $\mathrm{Sn}$ & 36.6 \\
$/$ glass & $\mathrm{ZnS}$ & 70
\end{tabular}

The microstructures of CZTS films were analyzed by X-ray diffraction (XRD, D/max $2500 / \mathrm{PC}, \mathrm{Cu} K_{\alpha}$, 
$\lambda=1.5406 \AA$ ) and the Raman spectroscopy. The Raman spectroscopy measurement was carried out with a Invia Raman spectrometer with excitation wavelength of $514 \mathrm{~nm}$. The morphology of CZTS films were investigated by scanning electron microscopy (SEM, S-570). The composition of CZTS films was determined by energy dispersive spectroscopy (EDS, Genesis). The optical properties were analyzed by UV-visible spectrophotometer (UV-VIS, UV-5800PC).

\section{Results and discussion}

Figure 1 shows the XRD patterns of three kinds of precursors in Sample $1(\mathrm{Cu} / \mathrm{Sn} / \mathrm{ZnS})$ and the thin films after sulfurizing at $330,400,450$, and $500{ }^{\circ} \mathrm{C}$. The $\mathrm{Cu}_{6} \mathrm{Sn}_{5}$ phases are all observed in the three precursor thin films, which is due to that $\mathrm{Cu}$ atoms diffuse into the $\mathrm{Sn}$ film. After sulfurizing at $330^{\circ} \mathrm{C}, \mathrm{ZnS}, \mathrm{SnS}$, and $\mathrm{CuS}$ are observed. After sulfurizing at $400^{\circ} \mathrm{C}, \mathrm{CuS}$ are still observed in Sample $2(\mathrm{Cu} / \mathrm{Sn} / \mathrm{ZnS} / \mathrm{Cu} / \mathrm{Sn} / \mathrm{ZnS})$ and Sample $3(\mathrm{Cu} / \mathrm{Sn} / \mathrm{ZnS} / \mathrm{Cu} / \mathrm{Sn} / \mathrm{ZnS} / \mathrm{Cu} / \mathrm{Sn} / \mathrm{ZnS})$. After annealing at $500^{\circ} \mathrm{C}$, only the CZTS diffraction peaks (112), (200), (220) and (312) are observed in three kinds of thin films. The thin films are all preferential oriented to (112) plane.

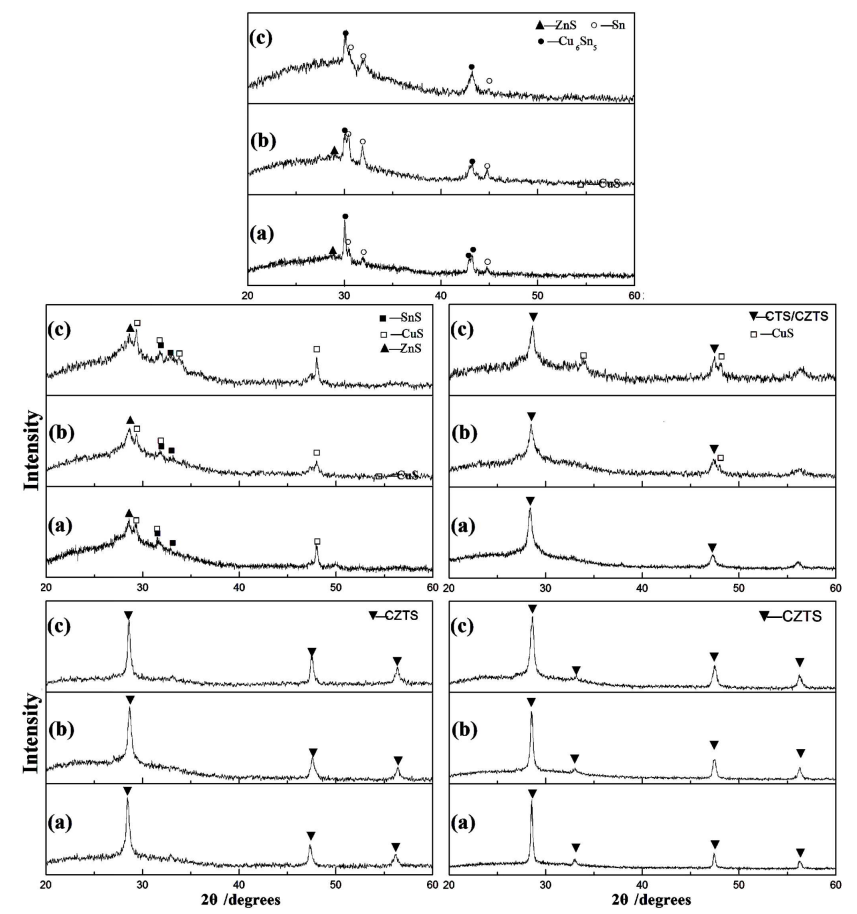

Fig. 1. XRD patterns of the precursors and the thin films after sulfurizing at different temperatures: (a) Sample 1, (b) Sample 2, (c) Sample 3; (top) precursor, (middle left) $330{ }^{\circ} \mathrm{C}$, (middle right) $400^{\circ} \mathrm{C}$, (bottom left) $450{ }^{\circ} \mathrm{C}$, (bottom right) $500{ }^{\circ} \mathrm{C}$.

The Raman spectra of three kinds of the thin films after sulfurizing at different temperatures are shown in Fig. 2. After sulfurizing at $330^{\circ} \mathrm{C}$, only $\mathrm{CuS}$ is observed in Sample 1. CZTS is also observed except $\mathrm{CuS}$

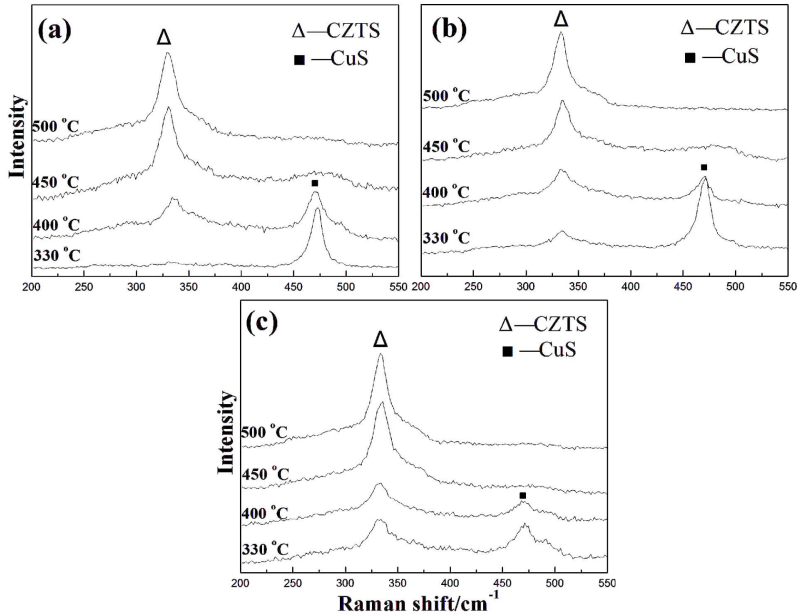

Fig. 2. Raman spectra of three kinds of the thin films after sulfurizing at different temperatures: (a) Sample 1, (b) Sample 2, (c) Sample 3.

in Sample 2 and Sample 3. With increasing cycle number, the intensity of CuS decreases and the intensity of CZTS increases. The increase of cycle number decreases the sulfurizing temperature of the formation of CZTS phase. The Raman spectra of three kinds of thin films after sulfurizing at high temperature are similar.

TABLE II

Atomic ratios of three kinds of thin films after sulfurizing at $500^{\circ} \mathrm{C}$.

\begin{tabular}{l|c|c|c}
\hline \hline & $\begin{array}{c}\mathrm{Cu} / \\
(\mathrm{Zn}+\mathrm{Sn})\end{array}$ & $\mathrm{Zn} / \mathrm{Sn}$ & $\mathrm{S} /$ metal \\
\hline Sample 1 & 0.92 & 1.22 & 1.00 \\
Sample 2 & 0.83 & 1.61 & 1.03 \\
Sample 3 & 0.68 & 2.03 & 1.04
\end{tabular}

Table II shows the atomic ratios of three kinds of thin films after sulfurizing at $500^{\circ} \mathrm{C}$. The content of $\mathrm{Cu} /(\mathrm{Zn}+\mathrm{Sn})$ decreases and $\mathrm{Zn} / \mathrm{Sn}$ increases with increasing cycle number. The content of $\mathrm{Zn}$ in the thin film increases obviously. It seemed probably that the adhesion between $\mathrm{ZnS}$ and glass substrate is less than that between $\mathrm{ZnS}$ and $\mathrm{Cu}$ layer. The control of chemical composition is one of the key factor in improving the efficiencies [7]. From Table II, chemical composition can be controlled by cycle sputtering deposition in some way.

The SEM surface images of the three precursor thin films were shown in Fig. $3 \mathrm{a}_{1}-\mathrm{c}_{1}$ and the SEM surface images of the thin films after sulfurizing at $500{ }^{\circ} \mathrm{C}$ were shown in Fig. $3 \mathrm{a}_{2}-\mathrm{c}_{2}$. The three kinds of the precursor thin films present uniform grain morphology and the particle size decreases with increasing cycle number. After sulfurizing at $500^{\circ} \mathrm{C}$, the three kinds of thin films exhibit compact and uniform grain characteristics. Different from the precursor thin films, the particle size of the thin films increases with increasing cycle number of thin film. 


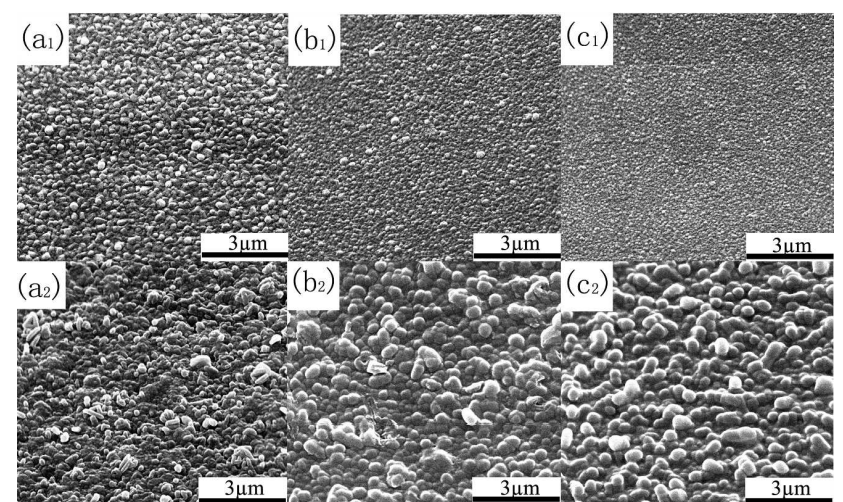

Fig. 3. SEM surface images of three kinds of the precursor thin films $\left(\mathrm{a}_{1}-\mathrm{c}_{1}\right)$ and the thin films after sulfurizing at $500^{\circ} \mathrm{C}$ : $\left(\mathrm{a}_{2}-\mathrm{c}_{2}\right)$ : (a) Sample 1, (b) Sample 2, (c) Sample 3.

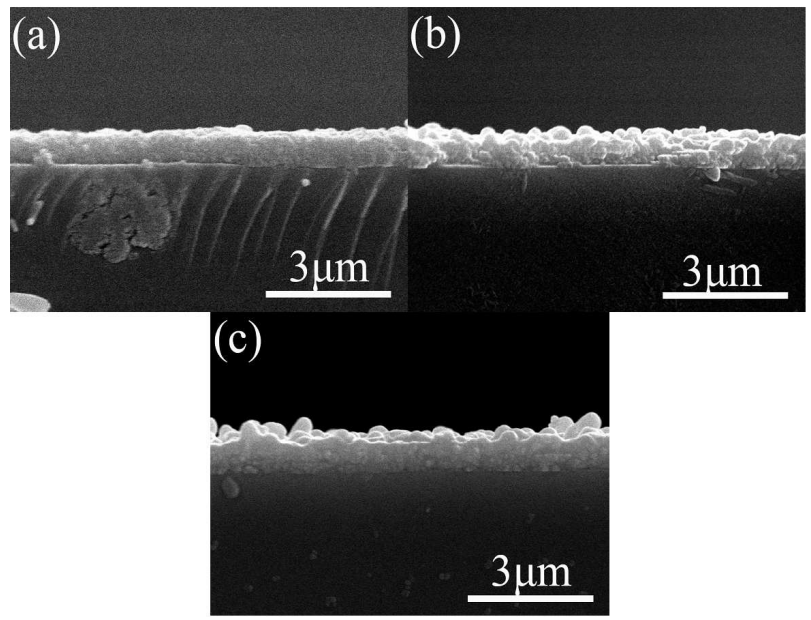

Fig. 4. Cross-section SEM images of three kinds of thin films after sulfurizing at $500{ }^{\circ} \mathrm{C}$ : (a) Sample 1, (b) Sample 2, (c) Sample 3.

The cross-section SEM images of three kinds of thin films after sulfurizing at $500^{\circ} \mathrm{C}$ are shown in Fig. $4 \mathrm{a}-\mathrm{c}$. The cross-sections of the thin films are all compact. There is little difference in the thickness of three kinds of thin films. The adhesion between the thin films and glass substrate improves with increasing cycle number of thin film, which can reduce the series resistance of the battery.

Figure 5 shows the transmittance spectra of three kinds of thin films after sulfurizing at $500^{\circ} \mathrm{C}$. The transmittance rate decreases in the visible light region with increasing cycle number of thin film. That is to say, the increase of cycle number enhances the absorption.

Figure 6 shows the plots of $(\alpha h \nu)^{2}$ versus the photon energy of three kinds of thin films after sulfurizing at $500{ }^{\circ} \mathrm{C}(\alpha$ is the absorption coefficient and $h \nu$ is photon energy). The band gap of the film is estimated by extrapolating the straight line of the $(\alpha h \nu)^{2}$ to the intercept of the $h \nu$ axis. The band gaps of three kinds of thin films annealed at $500{ }^{\circ} \mathrm{C}$ are estimated to be $1.55,1.58$

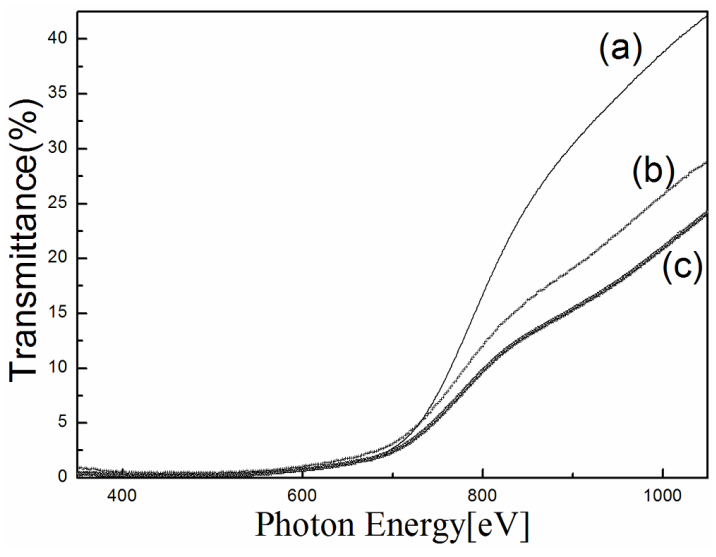

Fig. 5. Transmittance spectra of three kinds of thin films after sulfurizing at $500^{\circ} \mathrm{C}$ : (a) Sample 1, (b) Sample 2, (c) Sample 3.

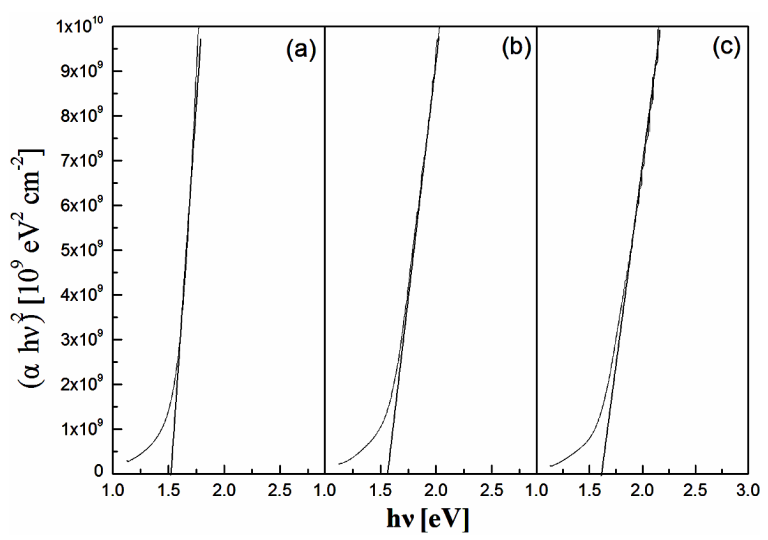

Fig. 6. The plots of $(\alpha h \nu)^{2}$ versus the photon energy of three kinds of thin films after sulfurizing at $500^{\circ} \mathrm{C}$ :

(a) Sample 1, (b) Sample 2, (c) Sample 3.

and $1.61 \mathrm{eV}$. The increase of cycle number increases the band gap of thin film, which is related to the decrease of $\mathrm{Cu} /(\mathrm{Zn}+\mathrm{Sn})[7]$.

\section{Conclusions}

Three kinds of precursor thin films with stacking orders of $\mathrm{Cu} / \mathrm{Sn} / \mathrm{ZnS}, \mathrm{Cu} / \mathrm{Sn} / \mathrm{ZnS} / \mathrm{Cu} / \mathrm{Sn} / \mathrm{ZnS}$ and $\mathrm{Cu} / \mathrm{Sn} / \mathrm{ZnS} / \mathrm{Cu} / \mathrm{Sn} / \mathrm{ZnS} / \mathrm{Cu} / \mathrm{Sn} / \mathrm{ZnS}$ were prepared by magnetron sputtering. The influence of cycle number on the properties of three kinds of thin films was studied. After sulfurizing at $500^{\circ} \mathrm{C}$, only the CZTS phase are observed in three kinds of thin films. The thin films are all preferential oriented to (112) plane. The increase of cycle number decreases the sulfurizing temperature of the formation of CZTS phase. The content of $\mathrm{Cu} /(\mathrm{Zn}+\mathrm{Sn})$ decreases and $\mathrm{Zn} / \mathrm{Sn}$ increases obviously with increasing cycle number. The particle size of the thin films after sulfurizing at $500^{\circ} \mathrm{C}$ increases with increasing cycle number, which is different from that of the precursor thin films. The adhesion between the thin films and glass substrate improves with increasing cycle number. The increase of cycle number increases the band gap of thin film. 


\section{Acknowledgments}

This work is supported by the National Natural Science Foundation of China under grant Nos. 10874178, 11074093, 61205038 and 11274135, Specialized Research Fund for the Doctoral Program of Higher Education under grant No. 20130061130011, Ph.D. Programs Foundation of Ministry of Education of China under grant No. 20120061120011, Natural Science Foundation of Jilin province under grant No. 201115013, and National Found for Fostering Talents of Basic Science under grant No. J1103202.

\section{References}

[1] H. Araki, A. Mikaduki, Y. Kubo, T. Sato, K. Jimbo, W.S. Maw, H. Katagiri, M. Yamazaki, K. Oishi, A. Takeuchi, Thin Solid Films 517, 1457 (2008).
[2] S.W. Shin, S.M. Pawar, C.Y. Park, J.H. Yun, J.H. Moon, J.H. Kim, J.Y. Lee, Solar Energy Mater. Solar Cells 95, 3202 (2011).

[3] X. Zhang, X. Shi, W. Ye, C. Ma, C. Wang, Appl. Phys. A Mater. Sci. Process. 94, 381 (2009).

[4] Hyesun Yoo, JunHo Kim, Thin Solid Films 518, 6567 (2010).

[5] Z. Hua, X.C. Meng, Y.M. Sun, W.Q. Yu, D. Long, Mod. Phys. Lett. B 28, 1450210 (2014).

[6] Y.M. Sun, B. Yao, X.C. Meng, D. Wang, D. Long, Z. Hua, Acta Phys. Pol. A 126, 751 (2014).

[7] A.V. Moholkar, S.S. Shinde, G.L. Agawane, S.H. Jo, K.Y. Rajpure, P.S. Patil, C.H. Bhosale, J.H. Kim, J. Alloys Comp. 544, 145 (2012). 